DOI https://doi.org/10.30525/978-9934-588-92-1-38

\title{
СУЧАСНІ АСПЕКТИ РЕАЛІЗАЦІЇ ТА ЗАХИСТУ ОСОБИСТОГО НЕМАЙНОВОГО ПРАВА НА ІНДИВІДУАЛЬНІСТЬ
}

\author{
Манжосова О. В. \\ кандидат юридичних наук, дочент, \\ завідувач кафедри ичивільно-правових дисииплін \\ Чернівечького юридичного інституту \\ Начіонального університету «Одеська юридична академія» \\ м. Чернівиі, Украӥна
}

Особисті немайнові права $є$ однією 3 базових цивілістичних категорій, яка продовжує динамічно розвиватись та вимагає переосмислення їх змісту та ролі в сучасному інформаційному суспільстві. На сьогоднішній день, все більшої перспективи набувають думки, щодо оборотоздатності окремих особистих немайнових прав та можливості їх використання з комерційною метою. Це, зокрема, стосується права на індивідуальність, яке характеризується положеннями Цивільного кодексу України як особисте немайнове право, що забезпечує соціальне буття фізичної особи та забезпечує індивідуалізацію фізичної особи в суспільстві.

Аналізуючи існуючі наукові позиції можна відзначити, що найбільша увага змісту права на індивідуальність приділена Р. Стефанчуком, який пропонує розуміти його як особисте немайнове благо фізичної особи, що $\epsilon$ сукупністю психічних властивостей, характерних рис і досвіду кожної особистості, що відрізняють ії від інших індивідуумів. До структури індивідуальності включають низку особливостей фізичної особи, що пов'язані з іiі національною, культурною, релігійною, мовною та іншою самобутністю. Ці особливості можуть виражатися у: зовнішньому вигляді фізичної особи; їі голосі і мові; манері поведінки; інтелектуальному, культурному та освітньому рівні; інших характерних ознаках, що вирізняють фізичну особу серед інших. Сукупність усіх зазначених елементів може створювати певне цілісне сприйняття особи, як певного індивідуума, і охоплюватися загальним поняттям - стиль (імідж), що доволі близько межує та взаємопов'язане 3 поняттям ділової репутації. За своїм змістом, право фізичної особи на індивідуальність, полягає у можливості використовувати свою індивідуальність, тобто обирати будьяку з можливих форм та способів прояву своєї індивідуальності, якщо вони не заборонені законом та не суперечать моральним засадам 
суспільства [1, с. 210]. Інколи індивідуальність фізичної особи може бути використана нею також і задля отримання певного матеріального зиску. Можливим це стає завдяки створенню та просуванню персонального або особистого бренду.

На сьогодні, бренд, як цивільно-правова категорія $є$ предметом наукового інтересу. Так Т. Кузьменко запропонувала визначення бренду, як складного засобу індивідуалізації учасників цивільного обороту, товарів та послуг, що складається з основних та додаткових елементів (сукупності об'єктів права інтелектуальної власності), представлених у візуальній, звуковій, ароматній, тактильній та смаковій формах, які у своїй сукупності та взаємодії створюють уявлення про виробника, його товари чи послуги у свідомості третіх осіб, свідчать про відомість виробника, його товарів чи послуг, що ним позначені та безпосередньо впливають на рівень споживання товарів або послуг [2, с. 13], проте, узгоджена концепція персонального або особистого бренду, наразі є несформованою.

Персональний бренд, наразі, визначається як те, що інші люди думають про нас (ідеї та асоціації, які ми викликаємо в думках про наш вигляд, поведінку тощо) [3, с. 54]. Іншими словами, персональний бренд - це наш образ у свідомості інших людей; це те, як нас бачать i сприймають; це наш образ, який генерує додаткову цінність і створює вигоди для нас $[4$, с. 6]. При цьому, особистий бренд - складова іміджу, за яку споживач готовий платити більше за видимої відсутності відмінностей. Персональний або особистий бренд в сучасних умовах $\epsilon$ проявом реалізації особистого немайнового права на індивідуальність, а особистий або персональний брендинг можна розглядати як процес, за допомогою якого особа активно намагається керувати враженнями інших про себе, свої вміння, навички та досвід. В тому числі і за допомогою соціальних мереж, таких як Instagram, Facebook, LinkedIn, Vimeo, YouTube, особисті блоги тощо, у яких доступно багато інструментів для передачі власного бренду.

Ефективність розвитку та просування персонального бренду багато в чому залежить від сформованого іміджу (від англ. «image» - «образ», «зображення»), який розглядається як мислене уявлення про людину, товар чи інститут, що спрямовано формується у масовій свідомості за допомогою засобів масової інформації, соціальних мереж тощо. Імідж $\epsilon$ результатом та конкретною формою відображення предметів і явищ у світосприйнятті людини, тобто відчуття, уявлення, поняття, які на основі цього формуються, та сформульовані висновки. Виходячи 3 цього, можна стверджувати, що кожному об'єкту притаманний певний 
імідж, «забарвленість», «упізнаваність». Навіть його відсутність, вважає проф. Г. Г. Почепцов, - також імідж [5, с. 22]. Імідж створюється 3 метою формування конкретного ставлення до об'єкта в суспільстві і при цьому, поєднувати як реальні властивості характерні для об'єкта, так і вигадані. Проте, не можна не відзначити, що характер спілкування в соціальних мережах має свою специфіку, а отже існують загрози для формування позитивного іміджу та ризик його втрати.

Зважаючи на те, що імідж особи $є$ комплексним поняттям i формується шляхом поєднання таких складових як практичні дії (прийняття рішень), усні заяви, чутки, стереотипне сприйняття, репутація тощо [6, с. 345], слід відзначити, що існує необхідність правової регламентації права на репутацію, яким би охоплювалося право фізичної та юридичної особи на об'єктивну, повну та своєчасну оцінку їі, як фахівця у будь-якій сфері професійної чи іншої діяльності, та іiі діянь (поведінки) з боку суспільства, певної соціальної групи та окремих громадян, а також право на формування цієї оцінки та іiі використання [7, с. 19]. Слід відзначити, що в змісті будь-якого особистого немайнового права $є$ правомочність вимагати його захисту у випадку порушення і не тільки в «реальному» житті, але й в процесі спілкування в онлайнових соціальних мережах. Ця позиція підтримується, наприклад, Європейським судом 3 прав людини, який тлумачить положення Конвенції про захист прав людини i основоположних свобод i, зокрема, встановлює обов'язок забезпечення прав та свобод, як в реальному, так і у віртуальному просторі [8], а значить, посягання в соціальних мережа на ділову репутацію носія особистого бренду є підставою для звернення його за захистом свого особистого немайнового права. Окреслена проблематика набуває особливої ваги, та вимагає подальшого аналізу, адже саме репутаційні втрати завдані носію персонального бренду в соціальних мережах можуть нанести йому непоправну майнову шкоду.

\section{Література:}

1. Стефанчук Р.О. Особисті немайнові права фізичних осіб (поняття, зміст, система, особливості здійснення та захисту) : монографія. К. : КНТ, 2008. 626 с.

2. Кузьменко Т. С. «Бренд» як складний правовий засіб індивідуалізації учасників цивільного обороту, товарів та послуг : автореф. дис. канд. юрид. наук,:12.00.03 Одеса, 2011. 21 с.

3. Казакова Е. Маркетинг личности. Маркетинг и реклама. 2010. № 2. C. 53-57. 
4. Паламарчук В.А. Типологія форм самозайнятості. Проблеми підвищення ефективності інфраструктури. 2010. С. 25-29.

5. Почепцов Г. Имидж: от фараонов до президентов. Строительство воображаемых миров в мифе, сказке, анекдоте, рекламе, пропаганде и паблик рилейшенз : монографія. К. : АДЕФ-Украина, 2007. 328 с.

6. Ольшанский Д. В. Политический консалтинг. СПб. : Питер, 2005. $448 \mathrm{c}$.

7. Стефанчук Р.О. Захист честі, гідності та репутаиії 6 иивільному праві. Монографія. К. : Науковий світ. 2001. 307 с.

8. Конвенції про захист прав людини і основоположних свобод : від 04. 11. 1950p. URL: https://zakon.rada.gov.ua/laws/show/995_004.

DOI https://doi.org/10.30525/978-9934-588-92-1-39

\title{
ВПЛИВ ВОСННИХ ДІЙ І ТЕРОРИСТИЧНИХ АКТІВ НА ФУНКЦІОНУВАННЯ МЕХАНІЗМУ ЦИВІЛЬНО-ПРАВОВОЇ ВІДПОВІДАЛЬНОСТІ
}

\author{
Примак В. Д. \\ доктор юридичних наук,
}

професор кафедри міжнародного, цивільного та комериійного права

Киїського національного торговельно-економічного університету

м. Київ, Украӥна

Норми міжнародного права щодо захисту прав жертв злочинів (терористичних актів зокрема) і порушень міжнародного гуманітарного права, а також внутрішньо переміщених осіб значною мірою орієнтовані на визначення належних форм ефективного відшкодування завданої шкоди, серед яких чільне місце посідає питання матеріальної компенсації за майнові та немайнові втрати, що їх зазнають потерпілі особи.

Окреслені проблеми зумовлюють потребу у виявленні у порушеному контексті різноманітних взаємозв'язків положень міжнародного права, 3 одного боку, та норм i принципів інституту цивільно-правової відповідальності - з іншого. Водночас слід констатувати інтегральний, міждисциплінарний характер інституту відшкодування шкоди, завданої жертвам злочинів, терористичних актів, серйозних порушень міжнародного гуманітарного права і прав людини. При цьому сутнісну 